\title{
Sifat Fisiko-Kimia Edible Film Agar - Agar Rumput Laut (Gracilaria sp.) Tersubtitusi Glyserol
}

\section{Effect of Glycerol on Physico-Chemical Properties of Edible Film From Agar Seaweed (Gracilaria sp.)}

\author{
Annisa Setyaningrum, Ni Ketut Sumarni*), Jaya Hardi \\ Jurusan Kimia Fakultas Matematika Dan Ilmu Pengetahuan Alam Universitas Tadulako
}

\begin{abstract}
The research about synthesis of edible film made from agar of seaweed (gracillaria sp.) using glycerol as plasticizer. The research aims to identify the physico-chemical properties of edible film based on glycerol as plasticizer. This reseach appling concentration as a variable $(30,35,40,45,50 \%(\mathrm{w} / \mathrm{w})$ respectively). Edible film thickness was tested using a micrometer while for tensile strength and elongation was tested bya Universal Testing Machine. The best glycerol concentration was obtained at $45 \%$ which produced film with specification: $0.0167 \mathrm{~mm}$ of thickness, $57.18 \mathrm{~g} / 24$ hours. $\mathrm{m}^{2}$ of water vapor transmission rate, 14.23 $\mathrm{MPa}$ of tensile strength, and $12.75 \%$ of elongation.
\end{abstract}

Keywords: Agar, gracillaria sp., gliserol, edible film,

\begin{abstract}
ABSTRAK
Telah dilakukan penelitian tentang pengaruh penambahan gliserol pada pembuatanedible film dari agar - agar rumput laut (gracilaria sp.). Tujuan penelitian ini adalah untuk mengetahui sifat fisiko-kimia terbaikedible film berbasis agar dengan plasticizer gliserol. Penelitian ini menerapkan variasi konsentrasi gliserol antara lain 30, 35, 40, 45, dan 50\% terhadap massa agar-agar atas dasar (b/b). Sifat fisiko-kimia Edible filmyang diuji antara lain ketebalan menggunakan micrometer, laju transmisi uap air, kuat tarik dan elongasi masing-masing diuji dengan Universal Testing Machine. Konsentrasi gliserol terbaik diperoleh pada penambahan gliserol $45 \%$ yang memiliki ketebalan $0,0167 \mathrm{~mm}$, laju transmisi uap air sebesar 57,18 g/24jam. $\mathrm{m}^{2}$, kuat tarik sebesar 14,23 $\mathrm{MPa}$, dan elongasi sebesar $12,75 \%$.
\end{abstract}

Kata kunci: Agar-agar, gracillaria sp., gliserol, edible film 


\section{LATAR BELAKANG}

Pengemas makanan banyakterbuat dari bahanplastik, karena memiliki beberapa kelebihan seperti fleksibel, mudah dibentuk, transparan, tidak mudah pecah dan harganya yang relatif murah. Namun, bahanplastik juga mempunyai kekurangan seperti tidak tahan panas, mudah robek dan dapat menyebabkan kontaminasi melalui monomernya, serta sifatnya non-biodegradable. Berdasarkan hal tersebut diperlukan pengemas bahan organik yang memiliki sifat mirip plastik namun bersifat biodegradable, seperti edible film (Wardhani dkk., 2010).

Edible film merupakan lapisan tipis yang digunakan untuk melapisi makanan (coating), atau diletakkan di antara komponen yang berfungsi sebagai penahan terhadap transfer massa seperti air, oksigen, dan lemak, bahkan dapat berfungsi sebagai pembawa bahan tambahan pangan. Khususnya edible film dengan sifat mekanik yang baik dapat menggantikan pengemas sintetik (Krochta dan Johnston, 1997).

Penggunaan agar-agar dari rumput laut yang dikombinasikan dengan gliserol dapat menghasilkan edible film yang kuat dan elastis, dan mempunyai sifat penghambat yang bagus terhadap uap air. Agar-agar dapat diekstrak dari rumput laut yang berasal dari kelompok Rhodophyceae, seperti Glacilaria dan
Gelidium. Tahun 2013, produksi rumput laut Gracilaria sp. di Sulawesi Tengah mencapai 105.506,8 ton (berat basah) (Dinas Kelautan dan Perikanan Sulawesi Tengah, 2013). Agar-agar adalah produk kering tak berbentuk (amorphous) dan mempunyai sifat seperti gelatin yang berupa rantai linear galaktan yang merupakan polimer dari galaktosa memiliki rumus molekul $\left(\mathrm{C}_{12} \mathrm{H}_{14} \mathrm{O}_{5}(\mathrm{OH})_{4}\right)$ n, dapat larut di dalam air panas dan dapat membentuk gel (Chapman dan Chapman, 1980).

Produksi edible film tidak lepas dari penggunaan plasticizer seperti gliserol. Gliserol efektif digunakan sebagai plasticizer pada hidrofilik film, karena mampu menghasilkan film yang lebih fleksibel dan halus. Menurut Gontard dkk. (1993), gliserol dapat meningkatkan permeabilitas film terhadap uap air karena sifat gliserol yang hidrofilik. Berdasarkan studi yang dilakukan Bergo et al., (2008), gliseroltidak hanya meningkatkan mobilitas rantai amilosa dan amilopektin, serta meningkatkan fleksibilitas film. Gliserol juga memiliki keunggulan dari plasticizer lainnya, seperti sorbitol. Cheng $d k k$. (2006), melaporkan bahwa pada kadar air tertentu, diperlukan konsentrasi sorbitol yang lebih tinggi dari konsentrasi gliserol untuk mencapai sifat elastic modulus (EM) dan tensile elongasi (TE) yang sama. Berdasarkan hal tersebut, maka 
dilakukan kajian tentang pengaruh penambahan gliserol dengan berbagai variasi konsentrasi terhadap sifat fisikokimia edible film berbasis agar-agar.

\section{METODE PENELITIAN}

\section{Bahan dan Peralatan}

Bahan dasar yang digunakan adalah agar-agar kertas dari rumput laut Gracilaria sp. Bahan lain yang digunakan yaitu air suling, gliserol, karboksi metil selulosa atau CMC sebagai penstabil, dan silica gel. Peralatan yang digunakan adalahhot plate WiseStir MSH 20-D, stirrer, oven Memmert, neraca analitik Adventure TM Ohaus, desikator, micrometer Krisbow, Universal Testing Machine Mesdan, dan alat-alat gelas lainnya.

\section{Prosedur Penelitian}

Pembuatan Edible film (Modifikasi metode Hidayat $d k k ., 2013$ )

Edible film dibuat dengan memanaskan campuran agar-agar dan aquadest dengan hot plate pada suhu 80$90^{\circ} \mathrm{C}$ dan diaduk dengan stirrer. Setelah 15 menit, ditambahkan CMC 30\%, kemudian diaduk lagi selama 15 menit. Selanjutnya ditambahkan gliserol dengan variasi 30, 35, 40, 45 dan $50 \%(\mathrm{~b} / \mathrm{b})$ terhadap total massa agar-agar dan CMC yang digunakan, kemudian diaduk lagi selama 15 menit dan dicetak pada cetakan film serta dikeringkan dalam oven suhu $50^{\circ} \mathrm{C}$ selama 2 jam dan didiamkan selama 24 jam pada suhu ruang. Edible film kemudian diukur ketebalan, laju transmisi uap air, dan sifat mekaniknya.

\section{Pengujian Edible film}

\section{Penentuan Ketebalan Film (Akili dkk.,} 2012)

Ketebalan film diukur menggunakan micrometer (ketelitian 0,001 mm) dengan cara menempatkan film di antara rahang micrometer. Untuk setiap sampel film yang akan diuji, ketebalan diukur pada lima titik yang berbeda, kemudian dihitung reratanya.

\section{Penentuan Laju Transmisi Uap Air} (Syarifuddin dan Yunianta, 2015)

Laju transmisi uap air terhadap film diukur dengan menggunakan metode gravimetri. Sampel film yang akan diuji dipotong sesuai ukuran yang direkatkan pada wadah yang telah berisi silica gel. Sebelum itu, silica gel dikeringkan pada suhu $105{ }^{\circ} \mathrm{C}$ selama 2 jam. Pengukuran dilakukan setiap hari selama satu minggu. Transmisi uap air dihitung dengan rumus:

$$
\mathrm{WVT}=\frac{G}{t \times A}
$$

Keterangan :

$\mathrm{G}=$ perubahan berat edible film (slope)

$\mathrm{t}=$ waktu

$\mathrm{A}=$ luas area permukaan film $\left(\mathrm{m}^{2}\right)$

Sifat Fisiko-Kimia Edible Film Agar - Agar Rumput Laut (Gracilaria sp.) 


\section{Sifat Mekanik (ASTM, 1996)}

Penentuan kuat tarik dan pemanjangan diuji menggunakan Universal Testing Machine (UTM). Kuat tarik ditentukan berdasarkan beban maksimum pada saat film pecah dan persentase pemanjangan didasarkan atas pemanjangan film saat film putus. Secara matematis hubungan tersebut dapat ditulis sebagai berikut :

$$
\text { Kuat } \operatorname{tarik}\left(\mathrm{N} / \mathrm{m}^{2}\right)=\frac{F}{A}
$$

Keterangan :

$\mathrm{F}$ : gaya kuat tarik $(\mathrm{N})$

A: luas penampang $\left(\mathrm{m}^{2}\right)$

$$
\text { Elongasi }(\%)=\frac{\Delta L}{L} \times 100 \%
$$

Keterangan :

$\Delta L$ : perpanjangan edible film $(\mathrm{cm})$

$\mathrm{L}$ : panjang awal edible film $(\mathrm{cm})$

\section{HASIL DAN PEMBAHASAN}

\section{Pengaruh Penambahan Gliserol} Terhadap Sifat Fisiko-Kimia Edible film

\section{Ketebalan}

Ketebalan adalah tebalnya edible film yang dihasilkan setelah pengeringan. Ratarata ketebalan edible film dengan menggunakan konsentrasi gliserol yang berbeda dapat dilihat pada Gambar 1 .

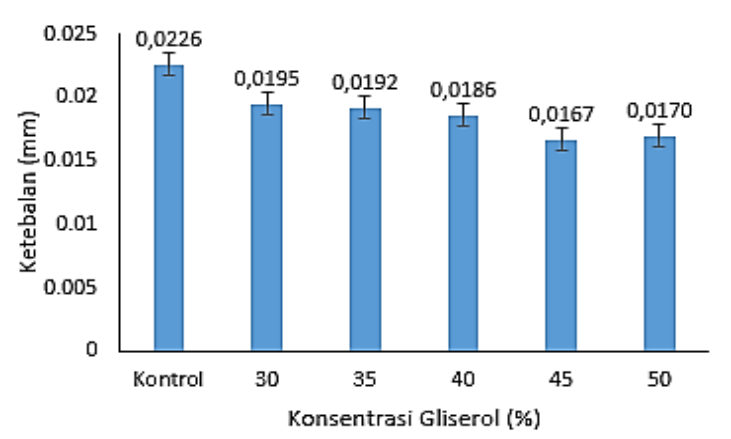

Gambar 1 Grafik Hubungan Konsentrasi Gliserol Terhadap Ketebalan Edible Film

(Kontrol : edible film tanpa gliserol)

Berdasarkan Gambar 1, dapat diketahui bahwa peningkatan konsentrasi gliserol cenderung memiliki ketebalan yang sama. Hasil uji ketebalan edible film tertinggi adalah 0,0195 $\mathrm{mm}$ yang diperoleh pada konsentrasi gliserol $30 \%$ dan yang terendah adalah $0,0167 \mathrm{~mm}$ pada konsentrasi gliserol 45\%, sedangkan kontrol ( edible film tanpa gliserol) memiliki ketebalan 0,0226 mm. Hasil analisis sidik ragam menunjukkan bahwa peningkatan konsentrasi gliserol berpengaruh tidak nyata terhadap ketebalan edible film $(\mathrm{p}>0.05)$.

Ketebalan edible filmini telah memenuhi standar ketebalan edible film yang ada menurut Japanese Industrial Standart (1975), yaitu maksimal memiliki ketebalan sebesar 0,25 mm. Hasil ketebalan edible film yang lebih tipis ini dapat disebabkan oleh sifat-sifat dari polimer penyusun edible film. Menurut Wang et al., (2010), ketebalan edible film 
dipengaruhi oleh sifat dan kandungan polimer penyusunnya. Jacoeb et al., (2014), melaporkan peningkatan konsentrasi gliserol dapat menurunkan ketebalan edible film berbahan dasar gliserol dankaragenan, hal ini disebabkan karena semakin tinggi konsentrasi gliserol terjadi penurunan pembentukan ikatan molekul sehingga pada saat pemanasan, terjadi kehilangan air yang lebih banyak sehingga menghasilkan ketebalan film yang lebih kecil.

\section{Laju Transmisi Uap Air (Water Vapor}

\section{Transmission Rate)}

Laju transmisi uap air adalah laju uap air yang masuk ke dalam edible film pada suhu dan kelembaban relatif tertentu. Berdasarkan Gambar 2, dapat diketahui bahwa hasil uji laju transmisi uap air edible film tertinggi adalah 57,96 g/24jam $\mathrm{m}^{2}$ yang diperoleh pada konsentrasi gliserol 50\% dan yang terendah adalah $57,18 \mathrm{~g} / 24 \mathrm{jam} \mathrm{m}^{2}$ pada konsentrasi gliserol $45 \%$, sedangkan kontrol memiliki nilai laju transmisi uap air 56,60 g/24jam $\mathrm{m}^{2}$.

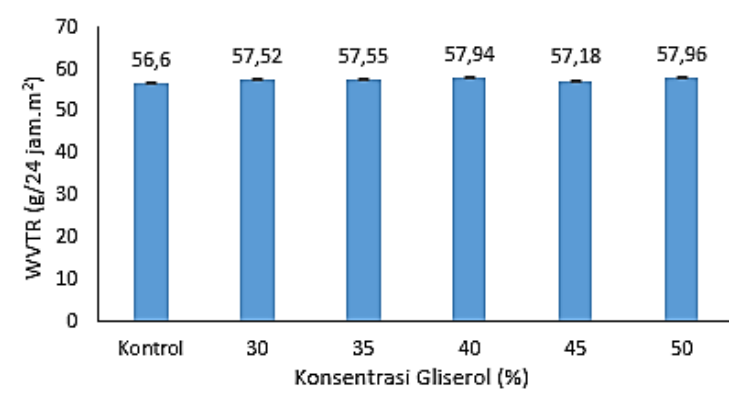

Gambar 2 Grafik Hubungan Konsentrasi Gliserol Terhadap Nilai Laju Transmisi Uap Air Edible Film.
Hasil analisis sidik ragam menunjukkan bahwa peningkatan konsentrasi gliserol berpengaruh tidak nyata terhadap laju transmisi uap air edible film( $\mathrm{p}>0.05)$. Hasil ini belum memenuhi standar nilai laju transmisi uap air menurut Japanese Industrial Standart (1975), dimana edible film maksimal memiliki nilai laju transmisi uap air sebesar $10 \mathrm{~g} / 24 \mathrm{jam} \mathrm{m}^{2}$. Hal ini dapat disebabkan karena laju transmisi uap air dipengaruhi oleh sifat hidrofilik dari bahan yang digunakan dalam pembuatan edible film. Agar-agar yang merupakan bahan dasar pembuatan edible film bersifat hidrofilik (Istini dkk., 2004). Gliserol juga memiliki sifat hidrofilik yang menyebabkan peningkatan laju transmisi uap air. Hal ini sejalan dengan pernyataan McHugh and Krochta. (1993), bahwa gliserol memiliki kemampuan yang tinggi dalam mengikat air sehingga menghasilkan nilai laju transmisi uap air yang tinggi. Gliserol juga akan menyebabkan penurunan ikatan hidrogen internal dan peningkatan jarak intermolekuler yang menyebabkan peningkatan permeabilitas edible film dan memudahkan perpindahan molekul uap air.

\section{Sifat Mekanik}

Kekuatan tarik merupakan tarikan maksimum yang dapat dicapai sampai edible film tetap bertahan sebelum putus. 


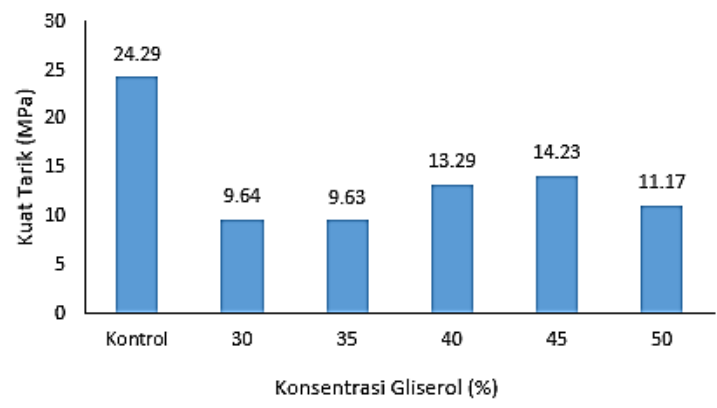

Gambar 3 Grafik Hubungan Konsentrasi Gliserol Terhadap Nilai Uji Kuat Tarik Edible Film.

Berdasarkan Gambar 3 menunjukkan bahwa hasil uji kuat tarik edible film tertinggi adalah 14,23 MPa yang diperoleh pada konsentrasi gliserol $45 \%$ dan yang terendah adalah 9,63 $\mathrm{MPa}$ pada konsentrasi gliserol 35\%, sedangkan kontrol memiliki nilai kuat tarik sebesar 24,29 MPa. Hasil uji kuat tarik ini telah memenuhi standar minimal kuat tarik yang ditetapkan oleh Japanese Industrial Standart (1975), yaitu memiliki kuat tarik minimal 3,92 MPa $\left(40 \mathrm{kgf} / \mathrm{cm}^{2}\right)$.

Menurut Nurfajrin dkk., (2015) peningkatan nilai kuat tarik dapat disebabkan oleh penambahan gliserol yang menyebabkan molekul-molekul penyusun film terdispersi semakin baik. Namun setelah mencapai titik optimal, penambahan gliserol pada film sudah melewati titik jenuh sehingga interaksi molekul penyusun film sudah tidak dipengaruhi oleh penambahan gliserol. Analisis sidik ragam menunjukkan bahwa konsentrasi gliserol berpengaruh tidak nyata terhadap kekuatan tarikedible film
( $p>0.05)$. Elongasi merupakan perubahan panjang maksimum yang dialami film sampai putus.

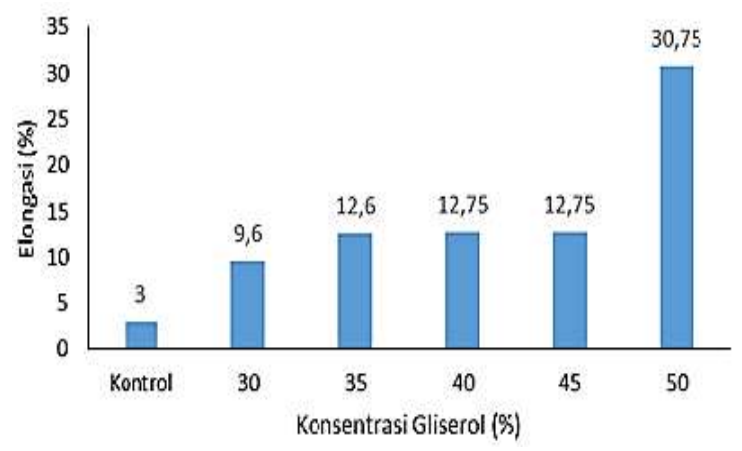

Gambar 4 Grafik Hubungan Konsentrasi Gliserol Terhadap Nilai Elongasi Edible Film.

Gambar 4 menunjukkan bahwa hasil uji elongasi edible film tertinggi adalah $30,75 \%$ yang diperoleh pada konsentrasi gliserol 50\% dan yang terendah adalah 9,6 $\%$ pada konsentrasi gliserol 30\%, sedangkan kontrol memiliki nilai elongasi sebesar $3 \%$.

Analisis sidik ragam menunjukkan bahwa konsentrasi gliserol berpengaruh nyata terhadap elongasi edible film $(\mathrm{p}<$ 0,05). Namun hasil ini masih belum memenuhi standar nilai elongasi edible film menurut Japanese Industrial Standart (1975), dimana edible film minimal memiliki nilai elongasi sebesar $70 \%$.

Huri dan Nisa (2014), menyatakan bahwa perlakuan konsentrasi gliserol yang semakin meningkat mengakibatkan kemuluran dari edible film semakin meningkat, selain itu penambahan 
plasticizer sangat penting untuk mengatasi film yang rapuh dan meningkatkan fleksibilitas. Film yang dibuat tanpa penambahan plasticizermenyebabkan edible film sangat rapuh dan mudah pecah selama penanganan.

Berdasarkan hasil analisis sifat fisiko-kimia edible film yang meliputi uji ketebalan, laju transmisi uap air, dan sifat mekanik, konsentrasi gliserol $45 \%$ dapat meningkatkan sifat-fisiko kimia edible film dalam hal ini menghasilkan ketebalan 0,0167 mm, laju transmisi uap air sebesar $57,18 \mathrm{~g} / 24$ jam. $\mathrm{m}^{2}$, kuat tarik sebesar 14,23 $\mathrm{MPa}$, dan elongasi sebesar $12,75 \%$.

Berdasarkan hasil penelitian yang diperoleh, dapat disimpulkan bahwa penambahan konsentrasi gliserol $45 \%$ dapat menghasilkan sifat fisiko-kimia edible film terbaik masing-masing dengan sifat ketebalan 0,0167 mm, laju transmisi uap air sebesar 57,18 g/24jam.m ${ }^{2}$, kuat tarik sebesar 14,23 $\mathrm{MPa}$, dan elongasi sebesar $12,75 \%$.

\section{DAFTAR PUSTAKA}

Akili, M.S., U. Ahmad, dan N.E. Suyatma. 2012. Karakteristik Edible film dari Pektin Hasil Ekstraksi Kulit Pisang. Jurnal Keteknikan Pertanian 26(1):39-46.

ASTM. 1996. Standard test methods for tensile properties of thin plastic sheeting, D882-91. Annual book of
ASTM. American Society for Testing and Materials. Philadelphia.

Bergo, P.V.A., R.A. Carvalho, P.J.A. Sobral, R.M.C. Santos, F.B.R. Silva, dan J.M. Prison, 2007. Physical properties of edible films based on cassava starch as affected by the plasticizer concentration. Packaging Technol Sci. 21(2):85-89.

Chapman, V.J., dan C.J. Chapman.1980. Seaweed and Their Uses 3rd ed. Chapman and Hall Ltd. London.

Cheng, L.H, A.A. Karim, dan C.C. Seow. 2006. Effects of water-glycerol and watersorbitol interactions on the physical properties of Konjac Glucomannan films. $J$ Food Sci.71(2):62-67.

Dinas Kelautan dan Perikanan Sulawesi Tengah. 2013. Laporan Statistik Perikanan Budidaya Provinsi Sulawesi Tengah Tahun 2013. Dinas Kelautan dan Perikanan Provinsi Sulawesi Tengah. Palu

Gontard, N., S. Guilbert, dan J.L. Cuq. 1993. Water and Glyserol as plasticizer Affect Mechanical and Water Barrier Properties at an Edible Wheat Gluten Film. J. Food Science 58(1): 206-211

Hidayat, M.K., Latifah, dan S.M.R. Sedyawati. 2013. Penggunaan Carboxymethyl Cellulose dan Gliserol Pada PembuatanPlastik Biodegradable Pati Gembili. Jurusan Kimia FMIPA Universitas Negeri Semarang. Indo. J. Chem. Sci. 2(3):253-258.

Huri, D., dan F.C. Nisa. 2014. Pengaruh konsentrasi gliserol dan ekstrak ampas kulit apel terhadap karakteristik fisik dan kimia edible 
film. Jurnal Pangan dan Agroindustri 2(4): 29-40.

Istini, S., A. Zatnika, dan Suhaimi. 2004. Manfaat dan Pengolahan Rumput Laut. BPPT. Jakarta.

Jacoeb, A.M., N. Roni, dan P. Siluh. 2014. Edible Film from Lindur Fruit Starch with Addition of Glycerol and Carrageenan. JPHPI 17(1):14-21.

JIS. 1975. Japanese Industrial Standart 2 1707. Japanese Standards Association. Japan.

Krochta J.M,E.A., dan D.M. Johnston. 1997. Edible and Biodegradable Polymers

Film: Changes and Opportunities. Food Technology . 51(2):60-74.

McHugh, T.H. dan J.M. Krochta. 1993. Permeability properties of edible films. Ch. 7. In Edible Coatings and Films to Improve Food Quality. Technomic Publishmg Co. Lancaster. Pennsylvania.

Nurfajrin, Z.D., G.S. Mahendrajaya, S. Sukadarti, danE. Sulistyowati. 2015.Karakterisasi dan Sifat Biodegradasi Edible Film dari Pati Kulit Pisang Nangka (Musa Paradisiaca L.) dengan Penambahan Kitosan dan Plasticizer Gliserol. Prosiding Seminar Nasional Teknik Kimia Kejuangan Pengembangan Teknologi Kimia untuk Pengolahan Sumber Daya Alam Indonesia.Yogyakarta. ISSN 16934393

Syarifuddin, A. dan Yunianta. 2015. Karakterisasi Edible Film dari Pektin Albedo Jeruk Bali. Jurnal Pangan dan Agroindustri 3(4):1538-1547.
Wang, J., J. Sang, dan F. Ren. 2010. Study of the physical properties of whey protein : sericin proteinblended edible films. Eur Food Res Technology 231:109-116.

Wardhani, A. Prasetyaningrum, N. Rokhati, D.N. Kinasih, dan F.D. Novia. 2010. Karakterisasi Bioactive Edible film Dari KompositAlginat dan Lilin Lebah Sebagai Bahan PengemasMakanan

Biodegrdable.Seminar Rekayasa Kimia Dan Proses. ISSN : 14114216 